№ 35-1, F F $_{1}$ (Virginia 27 / Burley 38) № 35-2, $\mathrm{F}_{1}$ (Virginia 27 / Burley 38) № 36-5, $\mathrm{F}_{1}$ (Ternopilskyi 14 / Burley 38) № 26-2, $\mathrm{F}_{1}$ (Ternopilskyi 14 / Burley 38) № 27-5, $\mathrm{F}_{1}$ (Hostrolyst Rubin / Burley 46) № 25-2, which had the advantage over the female and male parent forms and are promising for further breeding.

\title{
References:
}

1. Savina, O. I., Vasyliv, T. V., \& Savin, S. A. (2005). Stvorennja idealjnogho typu sortiv tjutjunu za osnovnymy oznakamy [Creating the Ideal Type of Tobacco Varieties under Basic Characteristics]. Bulletin of Agricultural Sciences, no. 12, pp. 40-43. (in Ukrainian)

2. Khomutova, S. A., Salomatin, V. A., \& Kubakhova, A. A. (2014). Potencial novyh sortov tabaka dlya razvitiya tabachnoj otrasli. [Potential of New Tobacco Varieties for the Tobacco Industry Development] Politematicheskij setevoj elektronnyj nauchnyj zhurnal Kubanskogo gosudarstvennogo agrarnogo universiteta [Polytopical Internet electronic scientific journal of Kuban State Agrarian University], no. 102(08). Retrieved from: http://ej.kubagro.ru/2014/08/pdj/081/pdj (in Ukrainian)

3. Ivanitskyi, K. I., \& Salomatin, V. A. (2010). Sozdanie konkurentosposobnyh sortov tabaka dlya vozdelyvaniya po skvoznoj agro-pishchevoj tekhnologii [Creation of Competitive Tobacco Varieties for Cultivation according to the End-to-end Agri-food Technology] Nauchnye osnovy sozdaniya skvoznyh agro-pishchevyh tekhnologij proizvodstva tabachnoj produkcii vysokogo kachestva i povyshennoj bezopasnosti [Scientific principles for creating end-to-end agro-food technologies for the production of tobacco products of high-quality and increased safety]. SSI All-Russian Research Institute of Tobacco, Shag and Tobacco Products, pp. 373-414. (in Russian)

4. Kosmodemyansky, V. N., Psareva, E. N., \& Grebenkin, A. P. (1974). Metodiki selekcionnoj raboty po tabaku i mahorke [Breeding methods for tobacco and mapacho]. Krasnodar, p. 77. (in Russian)

\section{FUNCTIONAL DIAGNOSTICS IN MAIZE CULTIVATION}

\author{
Serhiy Petrenko ${ }^{1}$ \\ Olena Pshychenko ${ }^{2}$
}

DOI: https://doi.org/10.30525/978-9934-588-39-6-32

Formulation of the problem. In recent years, there has been a tendency in Ukraine to disappear from crop fields that can maintain soil fertility at a high level. Most agrarians prefer crops of intensive type of cultivation, which leads to different types of degradation, in particular agrochemical. Producers

\footnotetext{
${ }^{1}$ Sumy National Agrarian University, Ukraine

${ }^{2}$ Sumy National Agrarian University, Ukraine
} 
of agricultural products take care of the introduction of basic macronutrients and actively use «unlimited» reserves of trace elements from soil, which are direct parties to the law of restrictive factor [1]. The rational and reasonable mineral nutrition during the vegetation of the crop creates the conditions for obtaining the maximum possible formation of the crop.

Analysis of recent research and publications. For each plant species there are elements that determine the growth and development of the plant. For example: sunflower is demanding for potassium and boron, corn is sensitive to zinc and magnesium, wheat to copper, manganese and magnesium, sugar beet to potassium, magnesium and manganese [2].

It is known that changing soil and weather conditions may cause temporary unavailability of nutrients for plants or prevent their consumption. In this regard, it is important to monitor the condition of the plant at all stages of its life, and especially during the critical stages of development. In these issues, plant-soil diagnostics will help, which makes it possible to promptly make changes to the technology of application of fertilizers: dosage, timing, methods of their application, which makes it possible to significantly increase the cost-effectiveness and efficiency of agronomic measures [3].

Agrochemical soil analysis and leaf diagnostics are similar in that they allow to determine the content of the elements necessary for plant growth and development. However, there are significant differences between them. Yes, soil analysis is most useful for optimizing soil nutrition before sowing. Leaf diagnostics also provide more relevant and up-to-date information on the supply of plants with nutrients during the growing season and current nutritional problems. Particularly foliar diagnostics are important in the case of adverse external factors that complicate the absorption by the root system of soil nutrients (drought, heat, etc.) [4, p. 1].

Therefore, special attention should be paid to foliar diagnostics when growing crops using intensive technologies.

Functional diagnostics of plants should be associated with optimal timing of application of microfertilizers, which are directly dependent on the biological characteristics of the crop. In analyzes, special attention should be paid to those trace elements that are of primary importance for the development of this plant. For example, for corn, that element is zinc. It is desirable to make in certain phases:

- 5-6 leaves - corresponds to the III-IV stage of the organogenesis of the parachute and the I-II stage of the organogenesis of the cob;

- 8-10 leaves - corresponds to the VI stage of the organogenesis of the parachute and the IV stage of the organogenesis of the cob.

It should be noted, that it is during these stages of organogenesis that onetime nutrition is quite effective, because at this time in the corn generative 
organs that determine the future crop (fertility of male inflorescences and the number of grains in a cob) are formed. With a significant zinc deficiency, more nutrition is possible. They should start from the phase of four to six leaves. Previously, it is possible, but the area of the leaf surface in this case will be too small, which may reduce the efficiency of feeding [1].

The purpose of our research was to monitor the level of nutrition of plants, to identify the existing nutritional problems, namely the shortage of nutrients in the first stages of vegetation in corn hybrids, depending on the level of fertilizers and to identify the need for foliar nutrition by certain elements in case deficit.

Research methodology and conditions. In the conditions of the northeastern forest-steppe of Ukraine, the studies were carried out on the experimental fields of ISGPS NAAN in 2019 with corn hybrid of domestic breeding Zoryaniy. The experiment was laid against the background of the main cultivation of "plowing» with variants «without fertilizers» and when applied in the norm $\mathrm{N}_{100} \mathrm{P}_{45} \mathrm{~K}_{45}$.

To determine the degree of security of maize plants macro and microelements, we used a modern portable device for functional diagnostics «Agrovector» PF-014, designed to study the photochemical activity of chloroplasts. The principle of such studies is to compare the photochemical activity in the control variant and to add to the suspension of the chloroplasts the specific element whose content is determined. In the case of an increase in the activity of chloroplasts in comparison with the control (without the addition of elements) it is possible to state the lack of this element; at decrease - about its excess; at the same activity - about the optimal concentration in the plant. This method allows you to determine, for one hour, the shortage or excess of the main 14 macro- and micronutrients. According to the recommendations of the specified photometer, we selected the plant material for agrochemical analysis of maize for the first time in the phase of 3-4 leaves and the second time in the phase of 6-8 leaves, and took fully developed leaves.

Presenting main material. As a result of the studies, it was found that in the phase of 3-4 leaves on the control variant, among the macroelements, maize plants lacked the most $\mathrm{N}(100 \%)$ and P (73,3\%) and less $\mathrm{KCl}(21,7 \%)$. The supply of almost all trace elements was also insufficient, namely: $11,1-100 \%$ less than the optimum level for plants. The greatest shortage of plants was felt in Fe (100\%), Mo (47,8\%), Zn (46,7\%) and Mn (41,7\%) (Figure 1). 


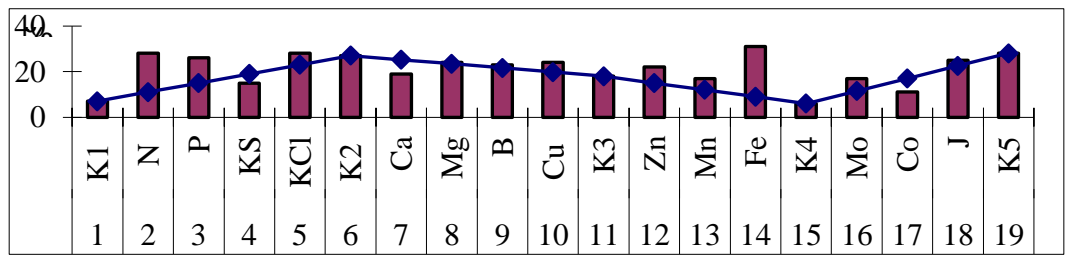

Figure 1. Security of hybrid Zoryaniy macro and microelements in phase 3-4 leaves for control in 2019

The introduction of mineral fertilizers changed the relationship between the supply of plants with macro- and microelements, in particular maize plants were fully provided with all macroelements. Along with this, the shortage of Fe, J, Mo (100\%), Mn (up to 91,7\%) increased sharply $\mathrm{Cu}(30,1 \%)$ and Zn (11,8\%) were insignificant (Figure 2).

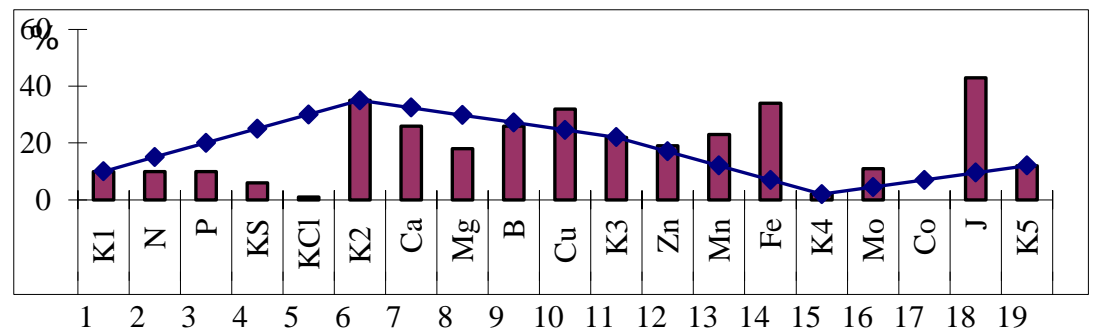

Figure 2. Security of hybrid Zoryaniy macro and microelements in phase 3-4 leaves with $N_{100} P_{45} K_{45}$ in 2019

Already in Phase 6-8 of leaf control, only potassium deficiency in both species increased (41,2-52,2\%), and phosphorus $(23,0 \%)$ and zinc (6,1\%) deficiency significantly decreased compared to Phase 3 -4 leaves. The number of other elements was within the normal range (Figure 3).

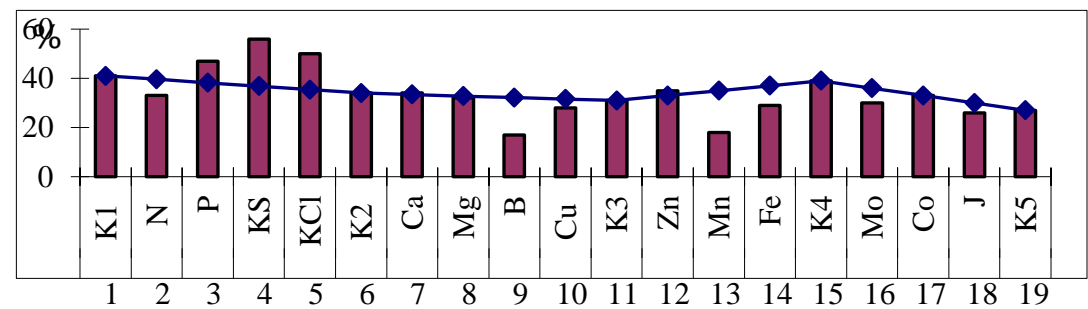

Figure 3. Security of hybrid Zoryaniy macro and microelements in phase 6-8 leaves for control in 2019 
Similar patterns for reducing nutritional deficiencies in the selection phases were observed in fertilizer variants. Only iodine deficiency (100\%) remained, and the lack of all other elements decreased and amounted to iron $(75,6 \%)$ and molybdenum (18,9\%). However, a small percentage of phosphorus deficiency (32,5\%) and cobalt (23,5\%) appeared in the second selection period (Figure 4). Compared to the control, fertilizer variants show a higher phosphorus deficiency (9,5\%) and a lack of iodine, iron, molybdenum, and cobalt. That is, even with the introduction of mineral fertilizers there is a decrease in the supply of plants with trace elements compared to the control, which in turn adversely affects the formation of corn yield.

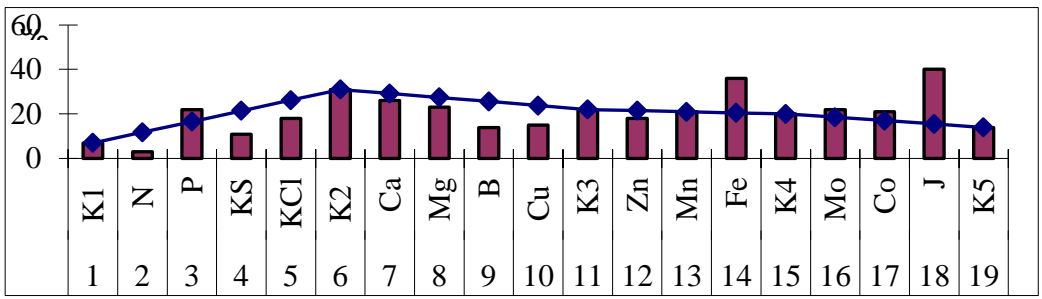

Figure 4. Security of hybrid Zoryaniy macro and microelements in phase 6-8 leaves with $\mathrm{N}_{100} \mathrm{P}_{45} \mathrm{~K}_{45}$ in 2019

Conclusions. Thus, all of the above indicates that in order to obtain high yields of corn, it is necessary to introduce not only NPK, but also necessarily other macro- and micro-elements, since the law on Boundary factors. Since leaf diagnostics can only determine the plant's need for a nutrient, it is possible to choose the optimum small dose of autumn when combining visual, plant and soil. Diagnosis with the most advanced means of research.

\section{References:}

1. Tarasenko O. (2017) Lystkove pidzhyvlennia zernovykh mikroelementamy [Foliar feeding of grain trace elements]. Propozytsiia (electronic journal), 14.04.2017. Retrieved from: https://propozitsiya.com/ua/listkove-pidzhivlennya-mikroelementamizernovih (accessed 18 March 2020).

2. (2019). Chutlyvist kultur do nestachi elementiv zhyvlennia [Sensitivity of crops to lack of nutrients]. Superahronom (electronic journal), 07.05.2019. Retrieved from: https://superagronom.com/multimedia/infographics/41-chutlivist-kultur-do-nestachielementiv-jivlennya (accessed 19 March 2020).

3. Izmodenova, T. (2016). Lystkova diahnostyka u roslynnytstvi [Plant tissue analysis in crop production]. Propozytsiia (electronic journal), 13.10.2016. Retrieved from: https://propozitsiya.com/ua/listkova-diagnostika-u-roslinnictvi (accessed 17 March 2020).

4. Kovalenko, O., Polyanchikov, S. P., \& Cowbell, A. I. (2014). Lystkova diahnostyka dlia optymizatsii zhyvlennia roslyn [Package diagnostics for optimization of plant nutrition]. Ahronom, vol. 8, no. 3, pp. 344-345. 